\title{
Efforts to Develop Children Fine Motor Skills Through Sticking Picture Properly by Using Combination of Explicit Instruction Model and Assignment Media Utilizing Natural Materials
}

\author{
Rina Fitriah*, I Nyoman Degeng, Utami Widiati \\ Graduate Program of Elementary Education, Universitas Negeri Malang, Malang, Indonesia.
}

\begin{tabular}{|c|c|}
\hline ARTICLE INFO & A B S T R ACT \\
\hline \multirow[t]{2}{*}{$\begin{array}{l}\text { Received: 09-03-2017 } \\
\text { Revised: 08-05-2017 } \\
\text { Accepted: 07-06-2017 } \\
\text { Keywords: } \\
\text { Learning outcome, } \\
\text { cooperative learning model, } \\
\text { STAD }\end{array}$} & $\begin{array}{l}\text { Learning outcome in this increasingly competitive era of globalization demands the } \\
\text { ability to think critically, creatively, communicate and collaborate and cooperation } \\
\text { including a good social skill. The meaning of learning outcome is the changes that } \\
\text { occur in the students, whether involving cognitive, affective, and psychomotor aspects } \\
\text { as a result of learning activities. Cooperative Learning Model of Student Team } \\
\text { Achievement Division (STAD) type emphasizes the activity and interaction among } \\
\text { learners that enable cooperation and socialization among students and help each } \\
\text { other in mastering the material to achieve a better learning outcome. }\end{array}$ \\
\hline & $\begin{array}{l}\text { (C) } 2018 \text { The Authors. Journal of K6, Education, and Management (j-K6EM). ISSN: } 2580-2135 . \\
\text { Published by Graduated Program of Educational Management, Universitas Lambung } \\
\text { Mangkurat, Banjarmasin, Indonesia. This is an open access article under the open journal } \\
\text { systems } 3 \text {. }\end{array}$ \\
\hline
\end{tabular}

*Author correspondence: Rina Fitriah; E-mail: rina.fitriah@gmail.com 


\section{Introduction}

In the regulation stipulated by the Minister of Education and Culture of Republic of Indonesia. No. 160 of 2014 on December II, 20I4, it states that the elementary and secondary education units implement Curriculum 2013. Learning in curriculum 2013 aims to develop the learner potential to have abilities in living as an individual and citizen who is faithful, productive, creative, innovative, and affective, and able to contribute to the life of community, nation, state, and civilized world (Regulation of Ministry of Education and Culture No. I04 of 20I4).

In curriculum 20I3, 2Ist century learning is expected to be implemented. The purpose is to address the demands of the increasingly competitive era. The 2Ist century learning reflects four things: critical thinking skill, creativity, communication, and collaboration. In curriculum 20I3, the curriculum objectives cover four competencies: spiritual, social, knowledge and skill competence (Minister of Education and Culture, 2016: 89). The learners are required to actively explore individual abilities in the learning process.

Nurhikmah (2010) in her research mentions that learning process should foster an active learner. This change should be reflected in learning activities. But before started, Supriyo (2017) suggests that teachers should have the information regarding the initial knowledge on the students. Teachers should be able to understand the self-efficacy of the learners in order to encourage students to have confidence to succeed in learning (Afandi, 2015).

Degeng (1998) suggests that a someone who learns is the subject of self-determination in learning. In other words, the only controller in learning is the person him/herself. Remember that every learner has different characteristics. There are learners who are active and those who tend to be passive in the learning process. Teachers should pay attention to the diversity of learners so that learning can be made into what is needed by the learners. Learning should be meaningful, meaning that learners are more likely to be the main actor in learning and teachers as facilitator and motivator (Akbar, 2016).
Student Team Achievement Division (STAD) is a cooperative learning model that emphasizes the activities and interactions among learners to mutually motivate and help each other in mastering the subject matter in order to achieve the learning objectives. In this model, teachers play a role as facilitator and motivator in learning.

The advantage of STAD is that the learners have group goals and individual responsibilities that encourage them to help each other and try as much as possible in achieving a better learning outcome. This might occur due to a sense of group and individual responsibility.

The scope of learning outcome in Curriculum 2013 includes aspects of attitude, knowledge, and skill, as well as the scope of learning outcome assessment by the Education Unit that includes knowledge and skill aspects.

\section{Methodology}

A good methodology should bring the researcher to achieve of the objective (Dalle, 2010; Dalle et al., 2017). This research used qualitative approach. In-depth and detailed observation was conducted to obtain the data. So that, it could collect the data completely and generate information indicating the quality. Qualitative research is conducted by describing the quantitative data which is in form of numbers, so it can be used to predict the wider population condition and the future (Aqib, 2006).

The qualitative data obtained were analyzed descriptively and then presented in form of numbers. While, qualitative data is presented in form of overview of children expression about the understanding level of activities (Arikunto, 2012).

The researcher is fully involved in qualitative approach as the main research instrument. Although there are instruments used such as camera, voice recorder, and image recorder, still the researcher is the main instrument. Because only the researcher who can empathize, build human interactions, capture, and understand the children perspectives (Son, 2013). 
In brief, classroom action research is a research reflected by the actors, to improve their rational stability and action in performing the task, deepen the understanding of the actions performed, as well as improve the practices of learning implemented. This classroom Action research stages include the stages of: a) planning, b) implementation, c) observation, d) reflection.

The factors studied in this research was the teachers factor of how to manage the learning process reflected on Daily Activities Plan, the children factor in form of children activities during the learning in the development of fine motor skills in sticking pictures properly and the factor of children development achievement.

There were three criteria used as the success indicators in this research. This research was said as successful if, a) Teacher activities that have been implemented achieved score of $\geq 32$ with very active criteria, b) Children activities achieved $\geq 82 \%$ with active and very active category, and c) The achievements results of physical aspects development of children fine motor individually at least achieved three stars $(\star \star \star)$, and classically $82 \%$ children earned at least three stars $(\star \star \star)$ or develop as expected of all the children.

\section{Results and Discussion}

\section{I Learning Outcome}

According to The Great Dictionary of the Indonesian Language of the Language Center "result is something made into existence (created, made, etc.) by effort". "Learning is trying to gain the intelligence or knowledge to change the behavior or response caused by experience". Learning relates to a person behavior change to a situation caused by his or her experience. Learning is a process of behavior change that is positive and relatively fixed in an individual. Changes in behavior caused by learning can be shown in various forms, such as the increase in knowledge, understanding, skill and attitude change of learners. Cronbach in Kompri (2016) states that learning is a show of behavior change as a result of experience.
Learning outcome is the ability of learners in accepting learning where behavior changes occur due to learning that includes the field of cognitive, affective and psychomotor. Nawawi in Susanto (2013) states that learning outcome is essential to find out whether someone attempt to acquire the new thing has been achieved.

In curriculum 2013, the learner learning outcome is specifically considered in terms of interest, potential and achievement. Learning outcome cover 3 dominant aspects. First is cognitive including intellectual ability such as knowledge, understanding, analysis, synthesis and assessment; second is affective aspect including emotional ability; and third is psychomotor aspect including motor skill in activating and coordinating the movement (Kompri, 2016). To find the learner learning outcome, we usually look at how the teachers measure how far student learning outcome that have been achieved. Assessment in 2013 curriculum refers to the Regulation of Ministry of Education and Culture No. 66 of 2013 on Education Assessment Standard. Assessment Standard aims to ensure: (I) learner assessment planning in accordance with the competencies to be achieved and based on the assessment principles, (2) implementation of student assessment in professional, open, educative, effective, and efficient way that is also in accordance with the socio-cultural context, (3) reporting the learner assessment results in objective, accountable, and informative way.

Learner learning outcome can be expressed qualitatively and quantitatively. Qualitatively, the learning outcome can be expressed as excellent, good, moderate, less and others. While quantitatively, learning outcome can be expressed by numbers.

\subsection{Cooperative Learning Model}

Cooperative learning is a form of learning in which the learners learning and working in a group in a collaborative and heterogeneous way (Rusman, 2014). Cooperative learning model is a strategy applied in learning through organizing by using small study groups where the learners work together to achieve learning objectives (Komalasari, 2010). 
The fundamental element that distinguishes cooperative learning model and regular group learning is on the process, here learning does not have to come from teachers to learners, learners can learn from each other. According to Rusman (20I4), this allows the teachers to manage the class more effectively. In the cooperative learning model applied by teachers, Nugroho et al. (2017) in his research suggests that teachers need to observe, understand and develop their motivation in learning. Sopalang (2017) mentions that cooperative learning can improve the achievement and quality of learning.

\subsection{Student Team Achievement Division (STAD)}

Student Team Achievement Division (STAD) is a model that emphasizes the activity and interaction among learners to motivate and help each other in mastering the subject matter in order to achieve maximum performance.

According to Slavin (2015), there are five main components in STAD cooperative learning model: (I) Class presentation, (2) Team, (3) Quiz, (4) Individual progress score and (5) team recognition. Learners learn to be responsible with their members to achieve learning outcome well because the score of individual progress will affect the score for each group. STAD can provide a positive effect for learners in learning and interacting between friends. In accordance with STAD main idea by Slavin, it is about making the learners to encourage each other and assist in mastering the skills taught by teachers.

The advantages in STAD are; (I) encouraging active and positive interaction and teamwork to be better, (2) helping learners to gain more crossracial friendship, (3) training learners in developing social skill in addition to cognitive skill. (4) making teacher role to be more active and more focused as facilitator, mediator, motivator and evaluator (Isjoni, 2010).

Yusuf et al. (2015) in his research shows that STAD can prevent clever students from dominating, so that all students play an active role. STAD can lead students in searching and finding the learning materials, which involves students actively in the learning process. This type of learning demands cohesion, responsibility and cooperation to establish empathy and positive enthusiasm. Ngatini (2014) in her research suggests that STAD is suitable for concept development but it should be modified with other models.

In STAD, the learners are divided into a group of four people with various abilities, gender, and tribe. The teacher provides a lesson and the learners in the group ensure that all group members can master the lesson that has been delivered. A research by Hariadi (20II) shows that with the application of STAD, there are significant differences in learning outcome. Djuli (20I6) in his research also shows that STAD affects the learning outcome.

STAD steps proposed by Rusman (20I4) are as follows; (I) Deliver the goals to be achieved on learning and motivate the learners to learn. Teachers motivate the learners by giving perception, finding the initial knowledge of learners by providing questions relating to the material to be taught. (2) Learners are divided into groups, each group consists of 4-5 learners that prioritize class heterogeneity in participants in terms of academic, gender, race or ethnic. (3) Teachers present/convey the subject matter first by explaining the learning objectives to be achieved at the meeting as well as the importance of the subject matter being studied. (4) Learners learn in groups that have been formed. Teachers prepare worksheets as guidelines for group work, so all members master and each member of the group contributes. (5) Teachers evaluate learning outcome by giving quiz about the material being studied and assessing the presentation of each group work. (6) Teachers check the student work and give scores ranging from 0-100. Furthermore, the award is given to the success group. Then, teachers and students conclude the learning together.

\section{Conclussion and Recomendations}

One of the efforts in achieving maximum learning outcome is by applying the learning model in accordance with the learner condition and learning objective. In the case of students who are still less active and not all learners can cooperate well, then the teacher can apply cooperative learning model of Student Team Achievement Division. 
STAD becomes one of the models that emphasizes the involvement and interaction among learners in learning process to mutually motivate and help each other in mastering the subject matter in order to achieve a better learning outcome. Students also have responsibility in the group to ensure that each member can answer the individual quiz since individual quiz might affect the group score.

\section{Acknowledgment}

No acknowledgment

\section{References}

Afandi, Z. (2015). Pengaruh strategi pembelajaran kontekstual dan efikasi diri terhadap hasil belajar sejarah siswa sma. Undergraduate thesis, unpublished, Universitas Negeri Malang.

Akbar, S., A'yun, I.Q., Satriyani, F.Y., Widodo, W., Paranimmita, R., \& Ferisa, D. (2016). Implementasi Pembelajaran Tematik di Sekolah Dasar. Bandung: Remaja Rosdakarya.

Degeng, I.N.S., (1998). Mencari paradigma baru pemecahan masalah belajar. Malang: Fakultas Ilmu Pendidikan IKIP Malang.

Djuli, L. (2016). Pengaruh metode jigsaw versus metode student teams-achievement divisions (stad) dan gaya kognitif terhadap hasil belajar membaca pemahaman siswa kelas viii smpn IO kota kupang. Unpublished Disertations, Universitas Negeri Malang.

Hariadi, B. (20II). Pengaruh strategi pembelajaran kooperatif tipe stad berbasis web vs teks dan gaya belajar terhadap hasil belajar mahasiswa. Unpublished Disertations, Universitas Negeri Malang.

Isjoni. (2010). Pembelajaran kooperatif meningkatkan kecerdasan komunikasi antar peserta didik. Yogyakarta: Pustaka Pelajar.

Komalasari, K. (2010). Pembelajaran kontekstual konsep dan aplikasi. Bandung: Refika Aditama.

Kompri. (2016). Motivasi pembelajaran perspektif guru dan siswa. Bandung: Remaja Rosdakarya.

Ngatini, W. (20I4). Penerapan model pembelajaran kooperatif tipe student team achievement division (stad) dipadu model talking stick untuk meningkatkan aktivitas dan hasil belajar matematika siswa kelas vi sdn pekauman I kota banjarmasin kalimantan selatan. Unpublished undergraduated thesis. Universitas Negeri Malang.

Nugroho, Y.S., Degeng, I.N.S., Sihkabuden. (20I7). Video Pembelajaran Cooperative Learning untuk
Tenaga Pengajar. Jurnal Pendidikan: Teori, Penelitian, dan Pengembangan. 2(3). 4I6-423.

Nurhikmah, H. (2010). Perbandingan hasil belajar dengan menggunakan model pembelajaran berbasis internet web centric course dan model pembelajaran konvensional pada mahasiswa yang memiliki tingkat self-efficacy. Disertation. Unpublished. Universitas Negeri Malang.

Rusman. (2014). Model-model pembelajaran mengembangkan profesionalisme guru. Jakarta: Rajawali Pers

Slavin, R.E. (2015). Cooperative Learning teori, riset dan praktik. Bandung:Nusa Media.

Sopalang, D. (2017). Penerapan model pembelajaran kooperatif jigsaw berbantuan mind mapping untuk meningkatkan aktivitas dan hasil belajar bahasa melayu siswa tingkat matthayom 2 (kelas $8 \mathrm{smp}$ ) patthanasaswitthaya school thailand. Unpbulished Disertation. Universitas Negeri Malang.

Supriyo. (2017. Pengaruh Strategi Pembelajaran Practice Generalization Reinforment (PGR) Vs Pembelajaran Langsung dan Pengetahuan Awal terhadap Hasil Belajar Tata Bahasa Bahasa Inggris Siswa Sekolah Menengah Pertama. Unpublished Disertation. Universitas Negeri Malang.

Susanto, A. (2013). Teori belajar \& pembelajaran di sekolah dasar. Jakarta: Kencana.

Yusuf, Y. Q. Natsir, Y. \& Hanum, L. (2015). A Teacher's experiensce in teaching with student teams-achievement division (stad) technique. International Journal of Instruction. 8(2). 99-I I2. 
ISSN 2580-2135 